\title{
MICROMORPHOLOGICAL CHANGES IN DOG KIDNEY CELLS INFECTED WITH MEASLES VIRUS
}

\author{
Jutaro TAWARA \\ Department of Microbiology, Okayama University Medical School \\ (Director: Prof. S. Murakami)
}

[受稿 4 月 16 日, 1964]

\section{INTRODUCTION}

The fine structure of the intranuclear and cytoplasmic inclusion bodies in measles was previously described by Kallman et al. (1959), Baker et al. (1960), and Tawara et al. (1961). Kallman et al. reported mainly about the fine structure of intranuclear inclusion bodies in HeLa cells, Baker et al. on that of crystallines of intranuclear inclusion bodies in human amnion cells, and Tawara et al. mainly about the fine structure of cytoplasmic inclusion bodies in dog kidney cells. The present paper deals with more precise fine structure of the fibrous filaments constituting these inclusions, as observed under the electron microscope of serial ultra thin sections.

\section{Materials ANd Methods}

A dog kidney, after removing the thin membrane, was eut into two halves along the renal pelvis, and the cortex was cut into fragments, $3-5 \mathrm{~mm}$ in diameter, which were washed several times with phosphate buffered saline solution. They were placed in a flask containing $0.2 \%$ trypsin solution previously warmed to $37^{\circ} \mathrm{C}$, kept at $37^{\circ} \mathrm{C}$ for 30 minutes, and trypsinization was continued at room temperature on a magnetic stirrer. Dispersed cells were collected at an interval of 15 minutes. The cell suspension was filtered through two sheets of sterilized gauze and the filtrate was centrifuged at 400 r. p. m. for 20-30 minutes. The sedimented cells were resuspended in YLE medium (yeast extract-lactalbumin Earle) containing $20 \%$ calf serum to make a suspension of about $2-3 \times 10^{5}$ cells $/ \mathrm{ml}$. The cell suspension was delivered with $1.0 \mathrm{ml}$ amounts into test tubes for stationary culture at $37^{\circ} \mathrm{C}$. On the second day of culture the medium was removed and the new YLE medium containing $5 \%$ calf serum was added. Two days later cell monolayers were formed and used for inoculation of virus.

Measles virus used was the Edmonston strain (Enders and Peebles, 1954) passaged in this cell which produced intranuclear inclusion bodies about 7 days after inoculation with a inoculum of $10^{3-4} \mathrm{TCID}_{50}$.

The techniques for electron microscopy and identification of inclusion bodies were the same as reported in the previous paper (Tawara et al., 1961). A Hitachi electron microscope HU-11 was used.

\section{RESULTS}

In hematoxylin-eosin stained specimens of dog kidney cells infected with measles virus cytoplasmic inclusion bodies were recognized under a light microscope 3 to 4 days after virus inoculation, and intranuclear inclusion bodies 7 to 10 days after inoculation. In the observations of the same specimen under electron microscope, however, both inclusion bodies in their early stage of development could be detected 2 to 4 days earlier. Namely, in the nucleus the inclusion body at an early stage of development was observed, as shown in Fig. 1, only 4 days after virus inoculation. Many fibrous filaments could be seen irregularly crossing each other in the region of inclusion body, and in some areas many filaments were aggregated in a strand-like structure. A crosssection of a cell cut parallel to the long axis of filaments is shown in the lower right corner of Fig. 1. Serial sections of this area of this cell were made and numerous consecutive sections of the aggregated filaments showed very different aspects as illustrated in Fig. 2. Filaments somewhat obliquely cut across the long axis are seen in an orderly array. In Fig. 3, an appearance of a crystalline arrange- 
ment is shown which obviously represents the pattern of filaments cut through vertically. At a high magnification, the filaments were found to have a long tubular structure as shown by a cross section view of the aggregated filaments in Fig. 4, an oblique section view in Fig. 5, and a longitudinal section view in Ffg. 6. The inner diameter of the filaments measures about $10-15 \mathrm{~m} \mu$, the outer diameter about $15-20 \mathrm{~m} \mu$, and some of the filaments in the longitudinal section view have a maximum length of over $450 \mathrm{~m} \mu$.

\section{Discussion}

Baker et al. described crystalline arrays in the cell 21 days after measles virus infection, apparently at a late stage of the development of inclusion body when the entire inclusion body was filled up with aggregates of fibrous filaments. The random filamentous structure reported by Kallman et al. on HeLa cells and by Tawara et al. on dog kidney cells seems to have been observed in inclusion bodies at their early stages of development.

The present study demonstrated that these different patterns observed in inclusion bodies merely represent different angles of section of filamentous structures. At an early stage of the development of inclusion body these filaments existed independently as a separate entity and at later stages they show more or less orderly parallel arrangement. Each filament has a tubular structure. This structure can be found in the nuclear and cytoplasmic inclusion bodies. However, neither the relationship between the cytoplasmic and intranuclear inclusion bodies nor the relationship of fibrous filaments. to virus is clear.

\section{SUMMARY}

In electron microscopic observation of serial ultra thin sections of intranuclear inclusion bodies of measles virus in dog kidney cells, filamentous fibers previously described in inclusion bodies were found to be of tubular structure, about $10-15 \mathrm{~m} \mu$ in inner and $15-20$. $\mathrm{m} \mu$ in outer diameter. These fibers occur randomly at early stages of infection but gradually aggregate to a compact form, presenting crystalline arrangement in the serial cross sections.

\section{ACKNOWLEDGMENT}

The author wishes to express his thanks to Prof. S. Murakami for his valuable advice.

\section{REFERENCES}

Enders, J. F., and Peebles, T. C. (1954). Propagation in tissue cultures of cytopathogenic agents from patients with measles. Proc. Soc. Exptl. Biol. Med. 105, 547-551.

Baker, R. F., Gordon, I., and Rapp, F. (1960). Electron-dense crystallites in nuclei of human amnion cells. Nature, 185, 790-791.

Kallman, F., Adams, J. M., Williams, R. C., and Imagawa, D. T. (1959). Fine structure of cellular inclusions in measles virus infections. J. Biophys. Bioch. Cytol. 6, 379-382.

Tawara, J. T., Goodman, J. R., Imagawa, D. T., and Adams, J. M. (1961). Fine structure of cellular inclusions in experimental measles. $\mathrm{Vi}$ rology, 14, 410-416.

\title{
麻牄ウイルス感染犬腎細胞に於ける微細形態的変化
}

\author{
俵 寿 太郎 \\ 岡山大学医学部微生物学教室（指導: 村上栄教授)
}

\footnotetext{
犬腎培養細胞に麻疹ウイルス Edmonston 株を感染 継代中であるが，感染細胞にはエオジン好性の細胞質 内及び核内封入体を認めることが出来た。

これを連続切片法で電子顕微鏡的に観察して, 核内 封入体部にみられるフィラメント様構造物は, 封入体 形初期には不規則に配列するが，後次第に凝集してき て束状となりつマとはこのもので封入体全部を形成
}

\author{
するに到るをものであることが判つた、これらのフィ \\ ラメント様構造物は，長いものでは $450 \mathrm{~m} \mu$ のもも \\ みられ，内径約 10-15 $\mathrm{m} \mu$, 外径約 15-20 m $\mu$ の管状構 \\ 造を有していた。そしてこのものとウイルス粒子との \\ 関係は，未だ明かではないが，これは麻瘆少ィルス \\ よる感染の標識となるものであると考えられる。
}



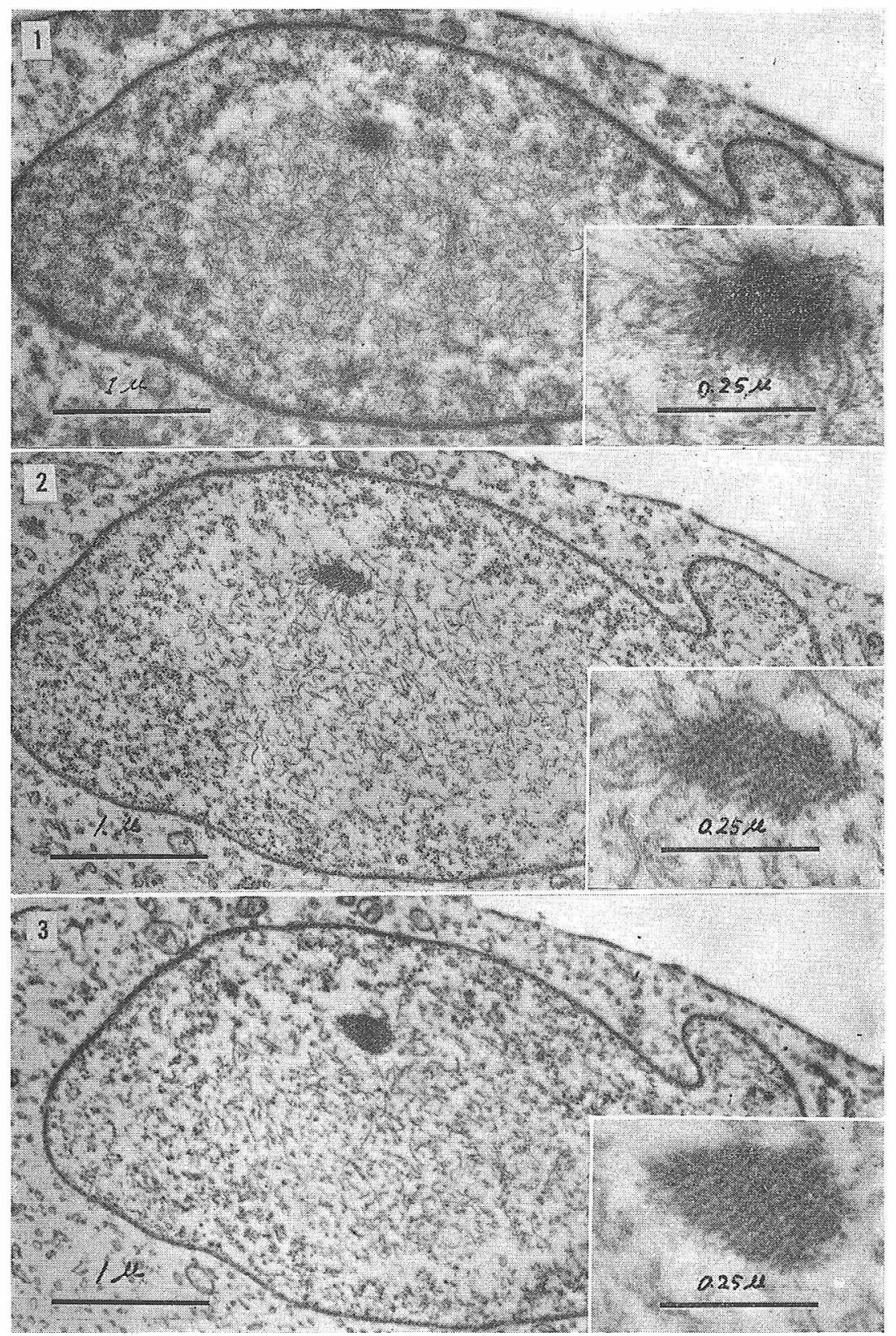

Fig. 1 shows a low magnification electron micrograph of intranuclear inclusion area in a dog kidney cell infected with Edmonston strain of measles virus. There are mass of fibrous filaments in one part of inclusion area, and the high magnification of this area can be seen at the lower right corner. It shows parallel view to the long axis of aggregated filaments.

Mag. $\times 24,900$ (low) Mag. $\times 99,600$ (high)

Fig. 2 and 3 show the different sections of the same cell shown in Fig. 1 and the high magnifications of aggregated filaments can be seen at the lower right corner. Fig. 2 shows the cross section somewhat obliquely at the long axis of filaments and Fig. 3 shows the cross section of filaments correctly.

Mag. $\times 24,900$ (low) Mag. $\times 99,600$ (high)

These three sections will show the situation of the filaments aggregation in an intranuclear inclusion body. 

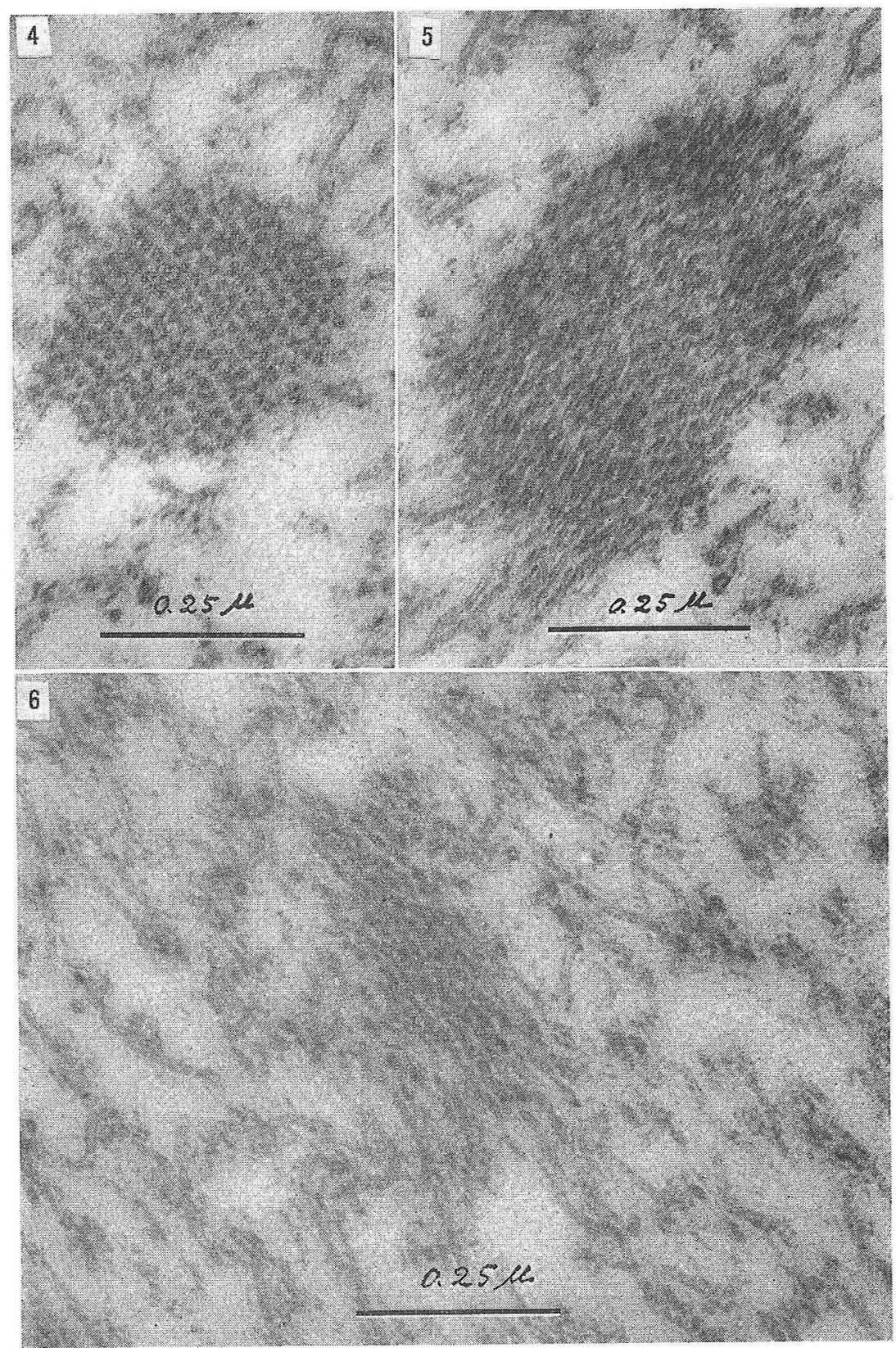

Fig. 4, 5 and 6 are the higher magnification of electron micrographs of aggregated filaments. They illustrate the cross section of aggregated filaments in Fig. 4, the oblique sections of them in Fig. 5 and the longitudinal section of them in Fig. 6. The filaments are seem consisting of long tube-like structures.

Mag. $\times 126,000$ 